\title{
O cabo-verdiano visto por cabo-verdianos ou contributo para uma leitura da situação linguística em cabo verde ${ }^{1}$
}

\author{
Mário Vilela
}

Professor Catedrático Jubilado da Faculdade de Letras da Universidade do Porto (Portugal)

\section{Introdução ou o ponto de partida da análise}

A situação linguística em Cabo Verde, segundo um dos melhores conhecedores da cultura, história e enquadramento cultural do Arquipélago, em comunicação pessoal, pode sintetizar-se do seguinte modo²: o Cabo-verdiano é uma língua única com variantes. Começar-se-ia com um pidgin em que os africanos das nove ilhas falavam com os chefes. Atualmente perdeu sentido a distinção entre "crioulo velho/fundo" e "crioulo levinho". No momento atual encontramos três tipos de situações:

i) bilinguismo total, em que os falantes percebem bem e exprimem-se bem nas duas línguas;

ii) bilinguismo parcial, em que os falantes percebem bem as duas línguas, mas exprimem-se bem em cabo-verdiano e mal em português;

iii) monolinguismo total, em que os falantes falam o cabo-verdiano e não percebem nem falam o português.

A continuação da variação deve-se ao ainda relativo isolamento de algumas ilhas - explica o Prof. João Lopes Filho -, a certo distanciamento entre o mundo rural e o urbano e à situação orográfica de algumas ilhas. Após o Vaticano II, é frequente ouvir-se homilias e a liturgia em Cabo-verdiano, informava ainda o mesmo investigador. Contudo, um dos mestrandos do «Seminário de Linguística» - também em comunicação pessoal - discorda da designação "monolinguismo total" - que não percebem nem falam português -, pois «todo o cabo-verdiano

1. Texto originalmente publicado na Revista da Faculdade de Letras: Línguas e Literatura, II série, v.21, Porto, p.633-653, 2005. Colaboração a pedido especial dos organizadores do livro em reconhecimento ao meu trabalho realizado ao longo de décadas em prol da Linguística em especial à Linguística africana.

2. Por feliz coincidência, pude passar com o Prof. João Lopes Filh, uma semana no mesmo apartamento na cidade da Praia, em Junho de 2005. João Lopes tem vasta bibliografia - é mesmo bibliografia essencial - sobre Cabo Verde. 
frequentou o catecismo e a liturgia, feitos em português."

Foi nesta situação, para mim inédita e deveras apaixonante, que tentei fazer uma leitura possível da situação linguística em Cabo Verde. Muni-me da bibliografia possível, inclusive dos livros, na minha opinião, mais autorizados ${ }^{4}$ e trabalhei com os dezoito mestrandos 5 , todos bilíngues totais, a quem agradeço a paciência e a colaboração. Sendo a minha competência do "crioulo" do ponto de vista "conhecimento activo" ou prático muito diminuta, eles compensaram, completaram, deram-me inclusivamente um "suporte" que, ao fim da estada em Cabo Verde, dava para acompanhar o fluir do discurso ${ }^{6}$.

Optei, para conseguir ter à mão uma leitura da situação linguística em Cabo Verde, por utilizar a opinião dos escritores - os representados na coletânea de entrevistas realizadas por Michel Laban, em afirmações situadas temporalmente na década de oitenta do século passado e a opinião atualizado de cabo-verdianos. Com auxílio dos mestrandos do Curso de "Estudos Africanos" da Universidade do Porto e de alguns Docentes do Instituto Universitário da Praia, adaptei um formulário de inquérito. Nos corredores do Instituto Universitário da cidade da Praia, falei com Docentes e com alguns Estudantes, a quem perguntei qual era a língua usada nos mesmos corredores, nas aulas, dadas em português, e se havia comentários entre Estudantes feitos em cabo-verdiano.

Farei uma breve introdução histórica usando os dados de todos conhecidos, uma leve definição de "crioulo" e, como ponto central, apresentarei a opinião de escritores e a "leitura" que um grupo de investiga dores/estudantes fazem da atual situação linguística em Cabo Verde. Procurarei sempre servir-me da opinião de quem vive ou viveu por dentro o problema.

\section{Alguns dos traços gerais da história de Cabo Verde}

Talvez pudéssemos sintetizar a visão linguística que Portugal - de que não me

3. Na minha experiência pessoal de três semanas de contacto permanente com cabo-verdianos, pude verificar, no meu dia-a-dia, quer o bilinguismo total, quer o bilinguismo parcial. Encontrei uma aluna do final do secundário, na altura em que tinha acabado de fazer exame de português e nem sempre percebia à primeira o que a minha mulher e eu dizíamos. Por outro lado, na catedral da Praia, a missa dominical foi sempre em português (com alguns traços próprios do português africano) e na igreja da Ribeira Grande verifiquei que a catequese estava a ser dada em português, como é evidente, com a cor e com alguns termos do cabo-verdiano. Nas ruas fala-se cabo-verdiano, mas entendiam-me sempre que abordava alguém.

4. Refiro-me essencialmente a Manuel Veiga, Dulce Almada, João Lopes.

5. Que são do melhor que encontrei na minha longa vida de professor (na Europa, no Brasil, em África e na Ásia).

6. Contei ainda com a presença sempre prestimosa da ex-doutoranda Lurdes Lima, que me serviu de suporte na autenticidade dos exemplos: o seu conhecimento do "Crioulo" é seguro e atualizado. 
excluo - tinha (ou teve) relativamente ao "crioulo" de Cabo Verde, como a de que a língua falada nessa colónia não passava de «um trambolho» linguístico. "Em toda a parte, estudam-se e cultivam os dialectos regionais; só em Cabo Verde que aparecem uns ilustres pedagogos a denunciar o crioulo como um trambolho, e se a mais não se atrevem é que se podem levantar as pedras das calçadas» (Cardoso, 1933). No entanto, essa língua é hoje falada por mais de um milhão de cabo-verdianos e seus descendentes, espalhados pela África, América e Europa, embora apenas cerca de um terço dos quais viva no Arquipélago. Esta ex-colónia portuguesa foi descoberta em 1460 por Diogo Gomes e António Nola quando voltavam da Guiné. Dois anos mais tarde, em 1462, fixaram-se os primeiros colonos portugueses em Santiago, fundando a cidade de Ribeira Grande, que se tornou importante placa giratória no comércio de escravos, cidade, que após ataque de piratas, ingleses e franceses, foi abandonada em 1712.

O fim (ou o declínio) da escravatura (1876), a corrupção e a má administração levaram ao esvaziamento da prosperidade das ilhas, prosperidade que foi de certo modo retomada no século XIX com a inclusão das ilhas nas grandes rotas entre a Europa, a América e a África do Sul e novamente perdida no fim da Primeira Guerra Mundial. Em 1951, a colônia portuguesa passou a província ultramarina, dez anos depois, os naturais foram considerados cidadãos portugueses de pleno direito. Nesta mesma altura, nasceu um movimento independentista, o Partido Africano para a Independência da Guiné-Bissau e Cabo Verde (PAIGC). Cabo Verde tornou-se república independente em 1975 e Aristides Pereira foi o primeiro presidente, mas em 1981 o PAIGC tornou-se Partido Africano para a Independência Cabo Verde e, nesse ano, foi aprovada a Constituição na Assembleia Nacional em que se formalizou a ruptura com a Guiné-Bissau.

Atualmente, Cabo Verde é uma república de regime multipartidário. Em 1999 a Assembleia Legislativa, num dos seus pontos de revisão constitucional, cria um novo estatuto para o Crioulo de Cabo Verde que passa a ser tido como «língua oficial em formação"7. Já, em 1998, foi criado o Alfabeto Unificado para a Escrita do Crioulo Cabo-verdiano, conhecido pela sigla ALUPEC. «O ALUPEC, como qualquer proposta, não representa uma solução definitiva em relação à escrita do Cabo-verdiano, tanto que os escritores em língua cabo-verdiana, ainda em número reduzido, saltitam frequentemente da escrita dita etimológica para a escrita fonético-fonológica» (Monteiro Cardoso, 2005, p. 13).

É um dado assente que o encontro de europeus e escravos africanos trazidos para Cabo Verde era mediado por uma comunicação construída num código

7. A partir desse momento, não acho correto chamar-se "crioulo" - termo de contornos conceptuais muito confusos -, pois deve apenas designar-se "cabo-verdiano". 
muito simples onde a linguagem verbal, auxiliada fortemente pela linguagem gestual, constituía o que se costuma designar por pidgin, predominantemente formada pelas palavras essenciais à vida do dia-a--dia e nomeadamente ao comércio. Passando-se ou não por um proto--crioulo, desagua-se no "crioulo": língua da comunidade e resultante do contacto permanente e sistemático dos povos de etnias africanas diferentes e europeus que permaneceram nas ilhas.

Actualmente, apenas os linguistas norte-americanos empregam esses termos em relação ao Cabo-verdiano (João Lopes Filho comunicação pessoal, em Junho de 2005). Para me servir da explicação de quem usa e conhece o Cabo-verdiano, nascido no Mindelo e aí exercendo a sua actividade: «O crioulo fundo será aquele que se afasta mais do Português, ou seja, aquele que é das comunidades mais afastadas dos centros urbanos, próprios das zonas rurais, com baixo ou nenhum grau de escolaridade, especialmente em Santiago e noutras ilhas de povoamento antigo ou muito isoladas....Falar um crioulo dito fundo, significa na prática falar com uma prosódia diferente, tanto no que toca à intensidade na pronúncia das palavras como no que se refere a uma entoação diferente é diatopicamente marcado [pela entrada mais antiga de vocábulos]. O crioulo leve ou levinho seria, então, aquele que está mais próximo do Português. É aquele que se ouve na boca dos falantes das vilas e cidades, dos que tiveram (ou cujos familiares tiveram) a sorte de terem frequentado o ensino oficial» (Monteiro Cardoso, 2005, p. 4). Este mesmo Investigador dá alguns exemplos de marcas diatópicas do vocabulário cabo-verdiano, relativamente ao que poderá documentar o dito "crioulo fundo".

O Crioulo apresenta atualmente um sistema gramatical, a nível fonológico, morfológico, lexical e sintático, solidificado, permitindo a comunicação normal entre os cidadãos e toda a atuação diária que é feita através da linguagem. As composições literárias, nomeadamente as líricas que servem de suporte às mornas e demais manifestações musicais são vazadas na Língua Cabo-verdiana. Ainda hoje surgem designações como "crioulo fundo" e "crioulo leve" ou "levinho" que parecem apontar para uma realidade cada vez menos verdadeira, por força da urbanização crescente nas ilhas.

\section{A questão "linguística" cabo-verdiana perspectivada pelos escritores}

\subsection{Para uma possível definição de "crioulo"}

Crioulo e crioulística - a disciplina que se ocupa do crioulo - não são termos de definição única. Há grupos de definição: um grupo parte do que podemos designar como "definição sócio-histórica", na medida em que definem os crioulos como as línguas que nasceram no decurso das colonizações europeias, em ambiente de escravatura, com uso estritamente oral e é nesse 
sentido que se passou também a designar os produtos e as pessoas dessas zonas geográficas. Assim, a noção de língua crioula aplica-se desde então ao campo bem delimitado dos estudos crioulos. O reagrupamento destas variedades linguísticas, normalmente muito diferentes, justifica-se por uma espécie de comparativismo por força das condições semelhantes quanto à gênese, desenvolvimento e evolução.

Poder-se-iam estudar essas línguas de modo separado, mas as aproximações entre elas parecem ser enriquecedoras para justificar a disciplina de "crioulística”. Entre essas condições sócio-históricas comuns, temos as relações geradas pela colonização, com a superioridade social do branco, o ambiente relativo à vida da escravatura (sociedades de habitação e plantação) e como consequência a influência das línguas europeias e das línguas, neste caso, africanas das populações em causa. Estas línguas de comunicação, transmitidas oralmente, sem qualquer suporte normativo que não seja a transmissão da mensagem, tornaram-se no único veículo de comunicação, quer entre senhores e escravos, quer entre os próprios escravos. Esta perspectivação do crioulo transformou a crioulística em sociolinguística: aliás, Laban (1992) dizia que qualquer linguística era necessariamente uma sociolinguística.

Outra perspectiva de crioulo - ou melhor, outro grupo de definições - parte da noção de tipologia linguística, em que o ponto básico é o de que a gênese das línguas se daria, para qualquer língua, em contextos de "contactos linguísticos". Isto é, o "tipo crioulo" estaria sempre em gestação em qualquer parte do mundo. Por outras palavras, a existência de crioulos leva a pensar que todas as línguas passaram pelo filtro da crioulização, mas a sua "crioulidade" escondeu-se numa normalização posterior. E, a ser assim, poderíamos falar de casos de "semi-crioulos" como as línguas que estão surgindo nos arrabaldes de cidades como Luanda e mesmo em Lisboa ou Setúbal. Estes crioulos serão línguas de contacto, susceptíveis de se dissolverem, como "interlectos", numa nova variedade, uma macro-língua, herdando todos os traços pertinentes, através dos "code-switching" que se foram retirando do "caos" linguístico entretanto criado.

Não vou entrar mais nesta discussão, pois, no meu entender, Cabo Verde encontra-se numa situação em que houve já uma reanálise, uma gramaticalização e gramatização: estamos perante uma língua, com variantes mais ou menos diferenciada ${ }^{8}$. Serve esta mini-introdução para afirmar que, na minha opinião, o Cabo-verdiano é apenas e tão-só uma língua e não deve ser metida no mesmo "saco" dos crioulos. 


\subsection{A "voz" dos escritores cabo-verdianos}

A questionação do papel, do estatuto, do lugar das línguas portuguesa e cabo-verdiana, surge no meio de muitos outros problemas - os que são postos aos escritores entrevistados - e que são de âmbito muito mais vasto, portanto bem para além da situação linguística de Cabo Verde. A língua apresenta-se aqui apenas como um dos tópicos postos perante os escritores. Por outro lado, as entrevistas foram todas feitas à volta de 1985 e desde então as coisas avançaram, como vimos anteriormente. As perguntas que selecionei, nos vários depoimentos, andam todas à volta do seguinte: qual vai ser o futuro do cabo-verdiano e do português em Cabo Verde? Eis um exemplo de resposta quanto ao futuro do cabo-verdiano:

Vejo o futuro da língua nacional em Cabo Verde com esperança. E esta esperança não deixará certamente de constituir um dos grandes desafios a enfrentar, quer pelo Poder, quer pelos estudiosos e cidadãos de boa vontade... O estatuto que se preconiza é o de língua oficial, tal como vem acontecendo com a língua portuguesa. (Varela da Silva, 1992, p. 777).

Mas para se ver a complexidade do problema do futuro do cabo- verdiano, há uma resposta onde os termos são percucientemente pertinentes, como descrioulização e as soluções alternativas, quer como a supradialectização quer como interdialectização:

O futuro linguístico [do cabo-verdiano] será a descrioulização, pura e simplesmente? Porque há quem defenda que o crioulo vai ser uma evolução em direcção ao português: o crioulo penetra no português e fica português. Será a descrioulização - será isto o futuro do crioulo? Ou então será o que eu chamo a supradialectização: quer dizer, o crioulo, muito bem, mas há uma variante //que se impõe, supradialectização - é uma variante que se impõe a todas as outras portanto, essa variante emerge de toda a situação dialectal e domina. Será esse o futuro do crioulo? Ou então o futuro do crioulo será uma interdialectização em que haverá uma unidade a partir da variedade... Uma unidade que resulta da adopção das variantes pertinentes e representativas da própria língua: há os dialectos todos. ... Mas falando do futuro linguístico de Cabo Verde, ..., antes de mais, é preciso aceitar que somos uma sociedade bilíngue "sui generis" - no sentido em que não posso dizer que Cabo Verde é uma sociedade bilíngue, porque o bilinguismo em Cabo Verde...- eu não posso dizer que toda a população é bilingue.... penso que vamos ter que caminhar para uma interdialectização equilibrada....»" (Veiga, 1992, p. 503s.)

Isto é, o futuro pode ser o aportuguesamento do cabo-verdiano (des crioulização), ou a supradialectização pela imposição de uma variante ou a interdialectização, em que o cabo-verdiano será o resultado das diferentes realizações das variantes existentes nas ilhas do arquipélago, criando-se uma macro-língua. Mas qual o papel do português e «em que circunstâncias se fala português em Cabo Verde» ou cabo-verdiano? Aliás as perguntas feitas aos escritores são colocadas directamente nestes termos: 
Os discursos às autoridades, os discursos por ocasião de casamentos..., as cartas de amor eram e são feitos em português, por duas razões essenciais: porque o português é a língua considerada de prestígio, por um lado e, por outro, por causa da dificuldade em se escrever em cabo-verdiano, por se tratar de uma língua essencial mente oral (só agora se começa a ensinar - de forma muito rudimentar - a escrita do cabo-verdiano) (Varela da Silva, 1992, p. 778).

ou, se se quiser destrinçar mais os campos de uso:

"Quando são problemas profundamente íntimos - afectivos, de ordem pessoal ou confessional - esses, acho que a melhor maneira de os dizer, é em crioulo. Mas, para mim, quando se trata, enfim, de veicular um poema onde haja problemas de ordem, vá lá, filosófica, se quiser, eu não acho outra maneira melhor de o fazer a não ser em português" (Osório, 1992, p. 447).

E o papel das duas línguas permanece claro e o espaço mais ou menos bem delimitado:

«Eu creio que as duas línguas, para nós, vão continuar a existir, cada uma no seu devido lugar. O crioulo tem que ter o seu lugar particular - eu costumo dizer que eu falo português, mas eu sou crioulo.... O crioulo nós criámos; o português, nós adoptamos», mas «se um dia ele [crioulo] vier a ser língua oficial, ele será a língua oficial ao lado do português» (Veiga, 1992, p. 597-598).

E qual a língua que o escritor deve usar nas suas produções? Não tenho dados muito claros do número de publicações atualmente existentes escritas em cabo-verdiano, mas já há um bom par de livros, coletâneas, ou centenas de folhetos e desdobráveis em língua da terra. A resposta dos escritores é mais ou menos clara:

Conquanto me sinta à vontade no manejo tanto da língua oficial como no da língua materna, penso que, para a veiculação e divulgação universal do nosso "estar no mundo", se deve utilizar a língua oficial» (Oliveira Barros in Laban, 1992: II, p. 545); «a língua veículo duma literatura cabo-verdiana, também virada para preocupações universais, terá de ser a língua portuguesa, jamais o dialecto crioulo (Teixeira de Sousa, 1992, p. 207).

Há uma opinião generalizada de que a oficialização do cabo-verdiano está a ver incrementar, naturalmente o conhecimento e normativização do "crioulo", mas, por outro lado, virá reforçar o ensino do português, com a abertura de "portais" para a sua leitura, e esta opinião está a generalizar-se:

Entrevistador: «Num país em que a maior parte das pessoas se exprime em crioulo, o poeta deve estar num dilema: utilizar o crioulo ou o português, não?

R: Eu acho que não... Na verdade, grande parte dos cabo- verdianos é bilíngue. Com o alastramento da alfabetização, da instrução em Cabo Verde - muitos já lêem -, e, de futuro, vão ler ainda mais o português» ${ }^{9}$ (Osório, 1992, p. 446).

9. É esta também a opinião de elementos do Instituto Camões da Praia. 
Todos conhecem a "cor" cabo-verdiana dos livros escritos em português, por parte dos escritores cabo-verdianos: trata-se de um "português" colorido, um "português sabi", cheio de "morabeza", cheio de roteiros e "cenários" que fazem ressoar reminiscências primitivas e com ecos históricos muito fundos. E é também essa a opinião dos próprios escritores e sirva-nos de exemplo o seguinte depoimento:

... o cabo-verdiano lê o livro [reporta-se a Voz de prisão] e sente-se identificado com a linguagem - é uma linguagem dele porque é uma língua híbrida. Porque é um português cabo-verdiano, crioulizado ... Às vezes será um crioulo aportuguesado ... isto é típico da comunicação em Cabo Verde ... Pertence à // raiz da comunicação: o cabo-verdiano pode falar só crioulo consigo; pode falar só português ou entre eles ... Mas pode misturar - muitas vezes mistura: às vezes começa em português, passa para o crioulo... (Ferreira, 1992, p. 142s.)

\section{A opinião da atual geração "culta" de Cabo Verde}

\subsection{A elaboração do formulário do inquérito}

Tendo ao nosso dispor um grupo de informadores de alto nível, sob todos os pontos de vista, todos nascidos em Cabo Verde, profissionais de primeira água e com uma atenta consciência política, procurei, com a sua colaboração, elaborar uma formulário adaptado às circunstâncias atuais, socorrendo-me do modelo de Valkhoff $\left(1975\right.$, p. 41-58) ${ }^{10}$. O inquérito parte da indicação:

- da língua dos pais e do lugar onde nasceram;

- do lugar onde nasceram e têm vivido os inquiridos;

- do número de publicações (livros, folhetos ou desdobráveis, coletâneas de todo o gênero) em crioulo e em português que cada um dos inquiridos possui;

- da idade em que começaram a aprender as duas línguas;

- da língua em que escrevem;

- de quais as línguas que falavam na escola (aula e recreio);

- da importância das duas línguas:

- para resolver problemas (querelas ou discussões) do dia-a--dia;

- para ser tido como culto;

- para escrever aos funcionários e autoridades;

- para falar aos funcionários;

- para cumprir os deveres religiosos;

- para falar com o chefe;

- para usar na rua, no trabalho, nas compras, nos bailes/divertimentos;

- para ler/compreender as regras e leis institucionais;

- para cantar numa festa popular.

10. Este modelo, por sua vez, era já uma adaptação do modelo aplicado em várias fases do levantamento linguístico feito no Brasil. 
O inquérito aponta ainda para o questionamento da diversidade da língua cabo-verdiana falada no ambiente familiar e na vida profissional. Depois, a inquirição volta-se para os pontos cruciais de uma política da língua (ou das línguas), concretamente:

- se acredita que o português vai substituir o crioulo;

- se o poder político deveria escolher uma só língua;

- com a oficialização do crioulo qual a variante cabo-verdiana que vai ser escolhida;

- sobre o que vai acontecer às demais variantes;

- se os políticos falam "crioulo" em público (como em campanhas eleitorais, conferências de imprensa, etc.).

Em termos de vida pessoal, em que língua fala

- com o cônjuge, com os seus pais, com os seus filhos, com os seus sogros, com os seus irmãos, com a namorada;

- com o seu chefe;

- nos transportes (barco, autocarro, avião);

- quando vai ao médico;

- quando conta dinheiro;

- quando canta;

- quando se zanga;

- quando sonha e quando acorda;

- em que língua pensa;

- se muda de variante quando muda de ilha;

- se na sua Instituição/no seu Bairro, há variantes de várias ilhas. Há outras perguntas importantes ${ }^{11}$ que não foram feitas no inquérito, como o problema do cabo-verdiano e o seu ensino, a relação da língua com a literatura, a oficialização do ALUPEC e, possivelmente, outros pontos igualmente importantes.

\subsection{A "voz" atual dos cabo-verdianos relativamente à situação linguística em Cabo Verde}

Os Mestrandos e as demais pessoas presentes no Seminário, duas dezenas, apontam para os seguintes tópicos:

- a língua dos pais é o Cabo-Verdiano (de uma pequena percentagem, português e cabo-verdiano) e todos tinham nascido em Cabo Verde. Todos os inquiridos nasceram em Cabo Verde, nas diferentes ilhas, mas como predominância para Santiago, Santo Antão e São Vicente. Alguns deles passaram por Portugal

11. Houve Mestrandos que, nas notas finais, chamaram a atenção para estas e outras questões que teriam merecido um "portal” no formulário: mas esses pontos ficarão para uma próxima oportunidade. 
(a maior parte), Estados Unidos e pela Rússia (1), pelo Brasil (1) e por Cuba (1); - o número de publicações (livros, folhetos ou desdobráveis, coletâneas de todo o gênero) em crioulo e em português que cada um dos inquiridos possui, se em português, todos possuíam (com predominância para os autores clássicos e para os autores cabo-verdianos que escreveram em português) e, por vezes, em número elevado; já em língua cabo-verdiana, ou não tinham qualquer exemplar, ou em número reduzido, havendo apenas um ou outro com número mais substancial. Todos começaram a aprender "crioulo" com o leite materno e apenas dois deles aprenderam na infância o português; os restantes aprenderam o português na escola (uns, aos sete e outros aos nove anos) ${ }^{12}$. Raramente escrevem em cabo-verdiano e fazem-no sempre em português, quer em blogues ou mensagens na "Net", ou mesmo entre amigos.

$\mathrm{Na}$ escola falavam português nas aulas e cabo-verdiano no recreio; dois deles falavam mesmo no recreio em português e em cabo-verdiano. Os professores permaneciam em contacto com os alunos nos intervalos e nos recreios;- a propósito da importância das duas línguas, para resolver problemas (querelas ou discussões) do dia-a-dia: para todos era o crioulo e apenas para dois dependia das situações; era o português a melhor língua para ser tido como culto, para escrever aos funcionários e autoridades, para falar aos funcionários; para cumprir os deveres religiosos e para falar com o chefe, a língua mais apropriada era o português, mas para usar na rua, no trabalho, nas compras, nos bailes/divertimentos (como para cantar numa festa popular), era o "crioulo" a língua mais adequada; para ler/ compreender as regras, leis institucionais, era o português, pois «é nessa língua que estão redigidos os documentos legais e institucionais».

Quanto ao questionamento da diversidade da língua "crioula" falada no ambiente familiar e na vida profissional, a maior parte afirma que é diferente, apontando para a maior liberdade comunicativa no ambiente familiar, como é normal e previsível. Uma coisa é o "estilo familiar" na comunicação, outra coisa bem diferente é a diversidade provocada pela variação da língua cabo-verdiana, como se indica por: "O crioulo falado em família é diferente: com o marido falo a variante do barlavento, com as filhas também a variante do sotavento (crioulo da Praia)"13.

Depois, a inquirição voltava-se para os pontos cruciais de uma política da língua (ou das línguas), concretamente: se acreditava que o português iria substituir

12. Embora todos eles sejam bilíngues totais, um deles, ao ser interrogado, sobre a duração da sua aprendizagem do português, afirma que ainda não concluiu esse aprendizado. Os trabalhos do Seminário foram redigidos em português: mas num "português", para a minha susceptibilidade da norma europeia do português, sem mácula.

13. Há duas referências deste gênero. 
o "crioulo"; e a resposta foi uma só e a maior parte qualificou o "não" com um "nunca". Embora, numa das respostas, surgisse um "talvez". Mas a pergunta que, a meu ver e no momento atual, é a mais premente - «se o poder político deveria escolher uma só língua (português ou cabo-verdiano)?» - teve como resposta generalizada: "não", «pois ambas fazem parte da raiz matricial de Cabo Verde"14.

Mas «qual a variante», com a oficialização do "crioulo", que vai ser escolhida e o que vai acontecer às demais variantes? As respostas giram à volta de vários pólos. Um dos pólos aponta para a variante de Santiago, o outro dilui-se entre o de "deixar o caminho livre" e uma via híbrida: o da chamada interdialectização ${ }^{15}$.

Quanto ao primeiro caminho, o da escolha da variante de Santiago ${ }^{16}$ :

«Em matérias linguísticas, os políticos não escolhem, digo melhor, não deveriam escolher uma variante em detrimento da outra. O que terão de fazer é obedecer aos estudos já feitos pelos peritos na área linguística. Ora, esses estudos até agora feitos apontam para a variante de Santiago como a mais representativa a nível do país, visto ter, de longe, mais peso linguístico, sociolinguístico e político. A variante de Santiago é falada por mais de metade da população de CV [Cabo Verde]»; e sobre o que vai acontecer às demais variantes ${ }^{17}$ :

Em certa medida a resposta já está dada no ponto anterior. Mas oficialização não significa padronização. Numa primeira fase de oficialização, haverá uma realização livre de todas as variantes, de Santo Antão à Brava. Numa segunda fase, impor-se-á a de maior força, que é, indubitavelmente, a de Santiago, por razões já apontadas, além de outras. A variante de Santiago, cedo ou tarde, será o dialeto padrão de Cabo Verde. É uma questão de tempo.

Ou ainda: "a variante de Sotavento, pelo seu maior afastamento em relação ao Português, por ser falado por um maior número de falantes e por o poder político estar radicado na Praia (Sotavento). Por outro lado, uma grande parte da elite cabo-verdiana, não sendo natural de Sotavento, escolheu a Praia para residir";

e sobre o que acontecerá às demais variantes:

«As demais variantes terão um papel relevante, pois elas complementam e enriquecem a variante de Santiago tomada como base».

14. Eis uma justificação, escolhida ao acaso: «O poder político deve sempre ter em consideração as duas línguas: o crioulo como língua materna e nacional e o português, como língua segunda, ambas em pé de igualdade para se evitar a situação de diglossia».

15. Pressinto aqui a "mão" teórica de Manuel Veiga que, aliás, os Mestrandos conhecem bem.

16. Seleciono, aqui, as respostas, que transcrevo ipsis verbis, que me pareçam as mais explícitas. Não podemos esquecer que a maior parte dos inquiridos nasceram em Santiago e todos vivem atualmente na capital (cidade da Praia).

17. Este investigador é natural de Santiago. 
Outro polo - o de deixar o caminho livre ao povo - sintetiza-se na seguinte afirmação:

"Com a oficialização do crioulo, qual a variante a escolher, neste caso não haverá consenso em termos de escolha, pelo que a sociedade deve ser ouvida e a escolha da mesma deve ser soberanamente respeitada e implementada».

Ou ainda:

«Com a oficialização do crioulo qual a variante que vai entrar em uso? Aquela que a sociedade cabo-verdiana escolher para os seus propósitos».

Sobre o que vai acontecer às demais variantes:

«Vão continuar a existir e a serem usadas pelos seus defensores e utilizadores, sem esquecer o sentido de preservação entendida no sentido de patrimônio de um povo».

Sem mencionar qual a variante, há quem defenda que «O poder político deveria escolher uma só língua em função das necessidades de padronização e de normalização da língua». Um terceiro pólo - o da evolução natural da sociedade e da osmose entre falares e pessoas - aponta para o que designam por crioulo de "inter-ilhas": "Qual a variante de crioulo do LCV que o poder político deve escolher? Fazer o filtro entre Barlavento e Sotavento (interilhas). E com a oficialização do crioulo qual a variante que: deixar a língua definir-se. E o que vai acontecer às demais variantes? Continuam a existir e vão enriquecer a variante que ficar»; e embora reconheçam um maior peso do crioulo do Sotavento, como vimos, deixam o caminho o caminho livre às demais variantes.

As demais variantes continuarão a ter um uso mais restrito, circunscritas às localidades onde originariamente são faladas; algumas desaparecerão pela sua proximidade com o crioulo da Praia (estou a pensar no crioulo que se fala no Fogo) e pela redução do número de falantes (crioulo que se fala na Boavista, por exemplo). Isso levará, penso eu, à uniformização (e não à bipolarização) do crioulo pela fusão das duas tendências que predominam - crioulo de São Vicente e da Praia. Mas a resposta mais global neste pólo - e vou transcrever na íntegra - é a seguinte:

"A LCV [Língua Cabo-Verdiana] e a Língua Portuguesa convivem de forma sadia no nosso país. É claro que há momentos em que só a língua portuguesa é e deve ser usada, assim como há momentos em que temos de nos valer da nossa língua materna. Existe a necessidade de valorizar a nossa língua, de oficializá-la e de fazer com que todos os cabo-verdianos saibam falar e escrever corretamente o crioulo. É certo que um dia será língua de ensino, mas no futuro próximo ela terá de fazer parte do currículo escolar como uma disciplina e depois paulatinamente o ensino;" 
"O poder político não deverá escolher uma só língua. Podemos conviver perfeitamente com as duas e é o que vem acontecendo mas já é tempo de o crioulo ser oficializado para ter o lugar devido, é uma língua como as outras;"

"Com a oficialização do crioulo qual a variante a escolher? O falante é que deve escolher. Cada ilha tem a sua e não se deve impor, mas deve haver sim uma unificação para a escrita»;

«Com a oficialização do crioulo qual a variante que vai entrar em uso? Para mim, nenhum. Se se escolher um, haverá problemas com os outros: questão de bairrismos». «O que vai acontecer às demais variantes? Todas vão continuar"18

$\mathrm{Na}$ pergunta sobre a consciência da diversidade do "crioulo" falado nas diferentes ilhas e mesmo dentro da mesma ilha (no caso de Santiago), a resposta mais geral a «se mudava de "crioulo" quando mudava de ilha e se era percebido pelos interlocutores», foi a de que não se mudava de "crioulo" e de que «era entendido» por todos e, inclusivamente, que no seu bairro ou instituição havia pessoas de várias ilhas. Mas há algumas respostas que vão num sentido bem diferente:

"Há cabo-verdianos que têm dificuldade em entender a minha variante: sobretudo os do interior de Santiago. As empregadas domésticas do interior de Santiago têm dificuldade em entende as ordens que eu lhes dou em crioulo de São Vicente. Tento aproximar--me do crioulo da Praia para que me entendam;"

"Quando muda de ilha muda de variante?: - Nunca, até porque tenho dificuldade em aprender as outras variantes. Há cerca de vinte anos que vivo na Praia, e nunca aprendi a falar o crioulo de Santiago. Tenho às vezes essa necessidade, acho bonito, expressivo, o crioulo de Santiago, sobretudo para cantar mornas, para intervir nos fóruns onde a maioria é de Santiago" 19

Acrescente-se ainda uma afirmação que indica a diferenciação:

"O crioulo falado em família é diferente: pois, com o marido falo a variante do Barlavento, com as filhas falo também a variante do sotavento (crioulo da Praia)."

Finalmente, houve quem não respondesse às perguntas e uma resposta diz expressamente o seguinte: "Qual a variante de crioulo da LCV que o poder político deve escolher? - Ainda não pensei. E com a oficialização do crioulo qual a variante que: - Deixar a língua definir-se. E o que vai acontecer às demais variantes? - Não sei”

Um dos Investigadores, em observações finais, acrescenta um dado que aponta para interessantes especializações de variantes: “As mornas, os finaçons, o batuque, são cantados no crioulo de Santiago, mas as coladeiras, não, utilizam

18. Esta investigadora viveu na Praia ( 8 anos), no Tarrafal (6 anos) e em Lisboa (2 anos).

19. "Mudo de variante quando vou à ilha de São Vicente, Mindelo, mais propriamente à minha aldeia" 
sobretudo o crioulo de São Vicente. A maioria das mornas, mesmo feitas por naturais de S. Vicente, utilizam predominantemente o crioulo da Praia. Razões?."

Em forma de rodapé, acrescento que, entre os Mestrandos inquiridos, encontrava-se um estudante português, cujas indicações são totalmente diferentes na maior parte das perguntas, e, apesar de muito jovem ainda, informa que aprendeu "crioulo" aos vinte e quatro anos e, no seu trabalho, mostra grande à vontade no domínio da língua da terra e usa-a no seu posto de trabalho, na resolução de discussões e problemas de todo o gênero, nas compras, na rua, nos divertimentos. Quanto à escolha de uma só língua por parte do poder político, não concorda e acha que se deveria optar pela variante de Santiago, embora seja de opinião de que as demais variantes se vão manter iguais. Por último, todos foram unânimes em afirmar que atualmente os políticos falam crioulo, acrescentando alguns, que isto acontecia sobretudos em período de eleições.

\section{Conclusão}

Estamos perante diglossia ou bilinguismo? Quanto à classe culta, não temos qualquer dúvida de que se trata de bilinguismo. Os Docentes do Instituto garantiram-me que falavam entre si em crioulo e o próprio Diretor do Mestrado em Cabo Verde, sempre que me acompanhava e falava com os seus pares, ora falava em "crioulo" ou em português indiscriminadamente: quando pedia qualquer coisa, fazia-o em qualquer das línguas, apesar da minha presença e sendo eu o "interessado" no pedido, pois tratava-se de coisas relacionadas com o Mestrado.

Nas ruas - com vendedoras de rua -, nos autocarros, no restaurante, no banco, na praia, no contacto com as crianças que brincavam nos largos, falei sempre em português e fui entendido. Isto é, a minha impressão é de que o bilinguismo (se não for total, será pelo menos parcial) funciona e existe. Passei grande parte do tempo na capital, mas também aconteceu o mesmo na Assomada, no Tarrafal. Por outro lado, acredito no depoimento que afirma o seguinte: «na minha ida às diferentes ilhas, constato que vai crescendo a uniformização do crioulo, sobretudo nos meios urbanos».

Todos apontam para o bilinguismo, ou seja, a oficialização e manutenção das duas línguas: «ambas são nossas». Ou, numa forma mais mitigada: «o português não substituirá nunca o crioulo, mas nas situações de maior formalidade o português vai-se sobrepor ao crioulo por muitos anos»», mas exigindo uma oficialização clara do "crioulo": «já é tempo de o crioulo ser oficializado para ter o lugar devido, é uma língua como as outras».

Qual a variante de "crioulo" da Língua Cabo-Verdiana que o poder político deve escolher e o que vai acontecer às demais variantes? As respostas vão desde: 
«deixar a língua definir-se» e as variantes "continuam a existir e vão enriquecer a variante que ficar depois da oficialização", pois "cada variante está ligada a uma região, a um grupo social e a uma história" e "traduz o sentir, o pensar e o jeito de ser de uma parte deste povo."

Até ouvir a população: "a sociedade deve ser ouvida e a escolha da mesma deve ser soberanamente respeitada e implementada», passando ainda pela exigência da unificação da escrita: «o falante é que deve escolher. Cada ilha tem a sua e não se deve impor, mas deve haver sim uma unificação para a escrita."

Finalmente, permito-me sintetizar a fotografia linguística de Cabo Verde com as notas finais de um inquérito: 1. Hoje há maior mobilidade de pessoas nas ilhas de CV e por isso há mais contacto entre falantes de outras variantes; 2. Espero que continue a crescer para que contribua para a construção natural de uma língua nacional. Embora os indicadores apontem para um acréscimo nos investimentos econômicos na capital, que tem atraído muitas pessoas das outras ilhas à procura de emprego; 3. Em suma, as outras ilhas poderão perder a sua variante linguística, uma boa parte da sua população ativa, sobretudo com a oficialização e ensino de uma única variante - a de Santiago -, que parece a estar a ser imposta.

\section{Referências}

Araujo, António Martins. Bilinguismo, diglossia e crioulização nos países lusófonos. Revista Portuguesa de Humanidades, v.8, p. 59-87, 2004.

Bartens, Angela. Der Kreolishe Raum: geschichte und gegenwart, Helsinki, Die Finnische Akademie der Wissenschaten, 1996.

Bartens, Angela. Caboverdeano em 45 lições. Estudo sociolinguístico e gramatical.s.d.

Cardoso, Pedro. Folclore caboverdeano. Porto: Marânus, 1933.

Carreira, António. O crioulo de Cabo Verde: surto e expansão, Lisboa: Gráfica Europam Lda, 1982.

Duarte, Dulce Almada. Bilinguismo ou diglossia?, 2.ed., Praia: Spleen [1999] 2003.

Ferguson, Charles. Language structure and language use. Califórnia: Stanford University Press, 1971.

Ferreira, Manuel. "Encontro com Manuel Ferreira”. Laban, 1992, II, p. 103-156, 1984.

Fishman, Joshua. Sociología del lenguaje, Madrid: Cátedra, 1982.

Fonseca, Aguinaldo Brito. «Encontro com Aguinaldo Brito Fonseca». Laban. I, pp. 247-258, 1992.

Fonseca, Mário. «Encontro com Mário Fonseca» Laban, II, p. 479-499, 1992.

Fortes, Corsino. «Encontro com Corsino Fortes» Laban, II, p. 383-422, 1992.

Laban, Michel. Cabo Verde. Encontro com Escritores, I e II vols., Porto, Fundação Eng. ${ }^{\circ}$ António de Almeida [As entrevistas foram feitas à volta de 1985, 1992]. 
Lopes, Baltasar. O Dialecto de Cabo Verde. Lisboa: Imprensa Nacional-Casa da Moeda. [1. ed., 1957], 1984.

Lopes, Baltasar. «Encontro com Baltasar Lopes» Laban, I, p. 11-55, 1992.

Lopes, Manuel. «Encontro com Manuel Lopes» Laban 1992, II, p. 61-98, 1992

Lopes, Manuel. La linguistique. Revue de la Société de Linguistique Fonctionnelle, v. 41, n.1 [Todo número é dedicado aos crioulos de base lexical francesa], 2005.

Monteiro Cardoso, Olavo Bilac Barbosa. Trabalho do Seminário de Linguística Africana, Praia: s.e., 2005.

Osório, Osvaldo. «Encontro com Osvaldo Osório» Laban, II, p. 427-450, 1992.

Romano, Luís. «Encontro com Luís Romano» Laban, I, p. 225-241, 1992.

Santos Lima, Maria de Lurdes. Confluência das linguas caboverdiana e portuguesa: perspectiva interdisciplinar, Porto [Tese de Mestrado], 2002.

TEIXEIRA DE SOUSA, Henrique. «Encontro com Henrique Teixeira de Sousa» Laban, I, p. 163-220, 1992.

Valkhoff, Marius F. «A Socio-linguistic Enquiry into Cabo-verdiano Creole». Miscelânea Luso-Africana. Colectânea de Estudos Coligidos por, Lisboa, Junta de Investigações Científica do Ultramar, p. 41-58, 1975.

Varela da Silva, Tomé. «Enontro com Tomé Varela da Silva» Laban, II, p. 769-782, 1992.

Veiga, Manuel. Diskrison Strutural di Lingua Kaburverdianu. Praia: ICL, 1982.

Veiga, Manuel. «Encontro com Manuel Veiga» in Laban, 1992, II, p. 561-607, 1987.

Veiga, Manuel (Coordenador). Proposta de Bases do Alfabeto Unificado para a Escrita do Cabo-Verdiano [ALUPEC], Praia (Aprovação: decreto-lei n. ${ }^{\circ}$ 67/98, de 31.12), BO n. ${ }^{\circ}$ 48, 1994.

Veiga, Manuel. Le créole de Cap-Vert: étude grammaticale descriptive et contrastive. Paris/ Praia : Éditions KARTHALIA et IPC, 2000.

Veiga, Manuel. A construção do bilinguismo. Praia: IBNL, 2004. 